\title{
Experiences of rail intermodal freight transport for low-density high value (LDHV) goods in Europe
}

\author{
Dewan Md Zahurul Islam* (1) and Thomas H. Zunder
}

\begin{abstract}
Objective: Previous studies have suggested an upward growth trend in low density, high value (LDHV) goods in Europe. Such goods require time sensitive, reliable services and currently, most LDHV goods are transported by road. The paper presents the findings of four case studies which detail the barriers and enablers to intermodal rail services for transporting LDHV goods.

Methodology: We applied a methodological pluralism, quantitative and qualitative, on an inductive basis. Using a case study approach, the research investigates the requirements of shippers, identifies key barriers to intermodal rail service offerings and, based on the findings, suggests enablers for intermodal rail freight transport. The current research applies parallel top down and bottom up streams, with a final integration synthesis.

Findings: Terminals may appear as an important barrier or enabler towards achieving a competitive intermodal rail service. By making rail terminal as an enabler, the research suggests that it is possible to carry LDHV goods by intermodal rail in a cost-efficient manner. The research attempts to seek a potential innovative solution to the barriers identified. The research compares road with an intermodal rail-road solution, in terms of cost and time, for a door-to-door service along the selected routes/corridors.

Recommendation: The research recommends that technical solutions, such as automated transhipment and temperature controlled systems, are required for rail freight services for LDHV goods, but that they must be complemented by collaborative operational solutions and viable service planning for an intermodal rail transport service to be reliable and competitive with road transport.
\end{abstract}

Keywords: Rail freight, Intermodal, LDHV, Barriers and enablers, Case study, Competitiveness, Logistics, Europe

\section{Introduction}

Transport service providers now operate in a competitive global market, with increasing pressure to reduce costs $[1,2]$ whilst simultaneously reducing the output of potentially harmful emissions [3-5]. Improvements in automotive propulsion technologies, e.g. Euro 1-6 standards and more aerodynamic road freight vehicle design, have resulted in lower emissions. These have been complemented by the goal of many shippers, operators and customers, as well as national and international policy makers [6], to better utilise non-road modes - especially rail and waterways within intermodal freight services. Rail is still largely seen as a more environmentally friendly mode $[7,8]$ and

\footnotetext{
* Correspondence: mzidewan@yahoo.co.uk

University of Newcastle Upon Tyne, Newcastle Upon Tyne NE1 7RU, UK
}

research into the benefits of using hybridised diesel engines for propulsion in European rail freight suggests further advantages to come, keeping the environmental case for rail freight strong [9]. For such intermodal services, the collection and delivery of cargo units can be performed by road, the long-haul section by rail [10], and the final delivery to cities, by trucks.

Despite the support of the EU in the form of the Railway Reform Packages 1 through 4, actual rail freight performance as a share of the market has been variable. At EU level, rail's share of the freight market has consistently fallen, against a background of rising total volumes. In the the new member states (EU12) - in many of which rail freight was dominant under Communism [11] -a downward trend can be noted, whereas in western 
member states (EU15) rail's share has slightly increased or remained the same [12]. Overall, rail's modal share of the freight movement in tonne-km declined from 13.6\% in 1995 , to $11.9 \%$ in 2011 [13] and further declined to $11.7 \%$ in 2014 [14]. With this reality in mind, in its 2011 Transport White Paper the European Commission set a target of 50\% modal shift from road to rail (and waterways) transport, by 2050, for distances over $300 \mathrm{~km}$. It continues to support this aspiration through policy, regulation, and research and innovation [6].

Whether aiming to achieve the EC modal shift policy, or increase rail's competitive ability to offer better service to shippers, novel techniques and methods could help to regain rail freight's previous level of modal share. A closer look at the market demands by cargo typology revealed rail to be shippers' first choice for low value high density cargo (e.g. sands, cement, coal, ore) [15] cargoes that can afford longer transit time and a certain level of unreliability. But the dominant and growing types of cargo in Europe are semi-finished and finished containerised goods, imported from relocated manufacturing factories in Asia Pacific, with traditional rail cargoes such as coal in sharp decline (e.g. in UK [16, 17]. Novelty needed to be found in this area, a gap in traditional techniques and methods for rail freight services.

Low density, high value goods (LDHV) require faster, more reliable, door-to-door transport services [18] and road is the preferred mode for hauls of around $200 \mathrm{~km}$. A recent study revealed that over longer distances, such as $500 \mathrm{~km}$, road transport dominates on many European corridors [19]. Examining the nature/characteristics of transport modes, we found that rail (and waterways) transport is dependent on road for door-to-door service, and requires transhipment in terminals, involving extra cost and time, as well as a higher risk of loss, damage and delay. This presents a challenging market for rail freight service providers, but also a significant opportunity. The potential LDHV market is estimated to be 1.9 billion tonnes, or $12 \%$ of the total tonnage currently transported by road, in the EU-27 and Switzerland $(\mathrm{CH})$, over distances of $200 \mathrm{~km}$. [18].

Bärthel and Woxenius [20] have suggested that, in freight transport markets, intermodal road-rail services work best for large flows over long distances. Behrends and Flodén 2010 suggest that intermodal liner trains can provide competitive services on short and medium transport distances if transhipment costs are kept low. Speed of travel $^{1}$ is a characteristic where rail freight is out of step with rail passenger trains, although it is still able to compete with road on overall transit times over long distances, as demonstrated on rail freight corridor services such as RETRACK, run by Transpetrol [11]. The average practical speed of a freight train is in the range of $60-65 \mathrm{~km}$ per hour (versus a theoretical speed of over $100 \mathrm{~km} / \mathrm{hour}$ ). In contrast, the average practical speed of a passenger train is much higher, at $90-120 \mathrm{~km} /$ hour for regional trains and 180-200 km/hour for high-speed trains.

The lower travel speeds for freight train stem from many factors, including acceleration and braking systems [21], priority of train paths being given to passenger trains in mixed running [12], an institutional neglect of rail freight in network planning [22]. The overall transit time of rail freight services can be affected by these and also other factors such as the stopping the freight trains at marshalling yards, terminals and borders, and operational processes that favour efficient utilisation of space/weight over the utilisation of time. To attract the shippers of time sensitive cargos, that customers wish to track in real time, rail freight transport operators must adopt novel tracking and tracing solutions that go beyond the tracking of trains by the infrastructure manager, and which instead track the goods themselves [15, 23].

This paper presents the findings of four case studies which detail the barriers to transporting low density, high value goods then, based on the findings, suggests enablers for LDHV intermodal rail freight transport.

\section{Paper structure}

Following this introduction, the research questions are posed and the methods used to answer them described. The findings section then presents the results of the research and explores their significance (similarities and differences, linked to improving rail freight services for LDHV goods) in the context of terminal operations and managerial practice, beginning to draw out a series of working recommendations. Next, the impact of this research on managerial practice and future service planning is discussed, followed by a final section that adapts these working recommendations into potential areas for further research, as well as detailing some of the ongoing or completed research that had an impact of this case study work.

\section{Research methods}

We applied a methodological pluralism, quantitative and qualitative, on an inductive basis. The intent was pragmatic, to identify barriers and opportunities in the single cases, for use in action by the companies concerned, to support commercial success through modal shift. In parallel, the research goal was to collect and triangulate data, looking for themes and common issues between cases in order to explore, describe and explain. One advantage of employing case studies was that the method can handle a large set of complex relations that are context dependent [24] and explain intricate and stable patterns. The methods and data collected and deployed were: desktop reviews of trade and academic literature; top down data collection, analysis and interpretation of 
statistical and company data; and bottom up analysis, using semi-structured interviews with key experts and responsible stakeholders.

In this paper we report research into four rail freight services, comprising: Procter and Gamble (P\&G), EURO CAREX, FloraHolland (GreenRail), and InnovaTrain. These cases are distributed for maximum analytical leverage (Robert K [25-27]). A range approach, from 'least likely' to 'most likely' was chosen, with the intention of collecting robust data for inductive research.

Collectively, the objective of the case studies was to identify barriers and enablers, as well as specify new market opportunities for rail freight transport, so that modal shift can be achieved. The case studies were expected to inform the design of feasible business models, under current and future rail assumptions and market scenarios. Considering the differences in technical and operational aspects, a flexible approach to methods (e.g. in the composition of the questionnaires) was used, in some instances incorporating a demand analysis for one or more cases. The remainder of this section discusses further the methodology applied in each case.

\subsection{Individual case methods}

Procter and Gamble (P\&G), is a multinational manufacturer of product ranges including family, personal and household care products; the case study consisted of:

\section{- A top down analysis:}

- A top-down desktop study: using primarily information published by $P \& G$ and other studies.

- A transport demand analysis: the iTREN tool was used [18]; iTREN combines four existing EU assessment tools to develop its scenarios ${ }^{2}$ :

1. TRANS-TOOLS - for transport networks;

2. TREMOVE - looking at the environmental effects of the transport sector;

3. POLES - simulating long-term energy scenarios for different parts of the world;

4. ASTRA - forecasting the long-term consequences of EU transport policies.

- Road transport statistics for LDHV goods, from the base year 2009. Estimated forecasts were made for the medium (2020) and long term $(2030)[18,28]^{3}$

- A bottom up analysis: to further affirm data on current and future freight volume, a specific network \{(Amiens (France) - Mechelen (Belgium) Euskirchen (Germany)\} was chosen for the analysis, together with $P \& G$, whose representative provided the information on their rail freight transport operations in Europe and the more specific data from the chosen network.

FloraHolland $(\mathrm{FH})$ are a Dutch conglomerate of florists. The case study was conducted by exploring the general horticultural market in Europe that FH handle, and by specifically collecting and analysing the GreenRail ${ }^{4}$ initiative case, where flowers and plants were transported by rail on the corridor between Rotterdam and Milan. Specifically:

- A top down study was conducted by collecting and analysing data using desktop research;

- A bottom up approach was applied by conducting interviews with a representative of FloraHolland working within the GreenRail initiative for transportation of horticultural products in Europe.

The EURO CAREX (a proposed high speed freight service) and InnovaTrain (a working Swiss rail freight service) case studies were conducted in two parts:

- A top down desktop study: to collect and analyse published statistical data in order to gain an appreciation of the current air cargo operations (to assess and to present the potential demand for the EURO CAREX service in the medium term (2020) and long term (2030), assuming that some of the high value air cargo can be captured by the proposed rail freight service). In the case of InnovaTrain, technical and operational data were collected and analysed.

- A bottom up analysis, to further affirm data on current and future freight volumes, cargo types, and quality and reliability of services, using interviews and questionnaires with potential users of EURO CAREX and of InnovaTrain.

\section{Findings}

\subsection{P\&G analysis}

The top down and bottom up analyses suggested that P\&G uses transport services for a variety of finished and semi-finished products. Producing and delivering these products to more than 4 billion customers worldwide generated large quantities of waste and carbon-dioxide emissions; bringing these products to market in a sustainable manner was therefore a major challenge for $\mathrm{P} \& \mathrm{G}$. Their cluster of manufacturing locations in Belgium, the Netherlands and the UK, whose products required distribution throughout Europe, provided an opportunity to look at aggregation of movements, elimination of truck miles, and empty running. P\&G work together with innovative transport and logistics service providers such as $\mathrm{P} \& \mathrm{O}$ Ferrymasters, branding themselves "GreenPort"; they have also implemented various transport chains 
based on shared cargo bundling with non-competing partners.

- Mechelen-Zeebrugge rail link to the UK: commenced July 2008; now supports 4 dedicated trains per day for $P \& G$ (now owned and operated by $\mathrm{P} \& \mathrm{O})$ with bi-directional traffic.

- Northern France to Spain (N-S) link between Dourges and Perpignan: commenced July 2008; six 45 -ft containers are typically loaded in each direction. Space is shared on existing (public) train services, to provide 2 connections per day. From Perpignan, the containers travel to a drop lot in Mataró in Spain, where incoming and outgoing containers are pooled. This way the truck can drop and reload without any waiting time. Distribution centres and the production plant in the Mataró area are handled by a separate local loop. Knowing in advance the exact timetable of these trains, $P \& G$ has managed to maintain the same or improved transit time, compared to a direct, truck-only route.

These two links eliminated 4.2 million truck-kms and saved 2,500 t of $\mathrm{CO}_{2}$ per year, in 2008/2009. ${ }^{6}$ An Italy/ Greece link was added in June 2009, which has consolidated freight from 10 different P\&G plants and/or DC's in Northern Europe, to serve Italy and Greece via a train dedicated to $P \& G$ products. $P \& G$ introduced the latest freight lane in its intermodal network, at the end of 2010. The new rail service is connecting P\&G's distribution centres via hubs in Duisburg (Germany), Muizen (Belgium) and Manchester (UK), three times per week, and uses the Channel Tunnel. Using trains to move goods has proved eight times more carbon efficient than relying on trucks and has allowed P\&G to halve the number of road miles in its supply chain. ${ }^{7}$

Although P\&G is a huge manufacturer and shipper globally, it did not have sufficient cargo to fill a full train load every day on a particular route. Following the novel application of game theory [29], P\&G identified the bundling of goods with other non-competing companies as its desired solution. In 2010, their logistics function established international transport corridors throughout Europe, along which P\&G trains moved not just their own products, but also goods from a range of non-competing brands, such as Baxter, Nike, Toyota and Ikea. This co-operation improved the efficiency of the train and reduced costs.

The Table 1 presents a summarized costs comparison between road ( $100 \%$ by road) and rail $(60 \%, 80 \%$ and $87 \%$ by rail and the rest by road). The Table shows the costs per year, when rail is used over a longer distance and no pre- and end-haulage is needed. Transportation at $80 \%$ by rail becomes a bit more attractive. Yet, the total costs and the costs per loading unit by rail are still slightly higher. This means, that for rail transport to become more attractive than road more goods would have to be transported by rail. The break-even point (compared to road) is achieved at $87 \%$ of the total cargo on the selected network.

Considering the findings, $P \& G$ needed to relocate the distribution centres (DCs) closer to terminal on the selected network. For example, the rail terminal of Cologne is closer (about $40 \mathrm{~km}$ ) to the $P \& G$ production plant/DC in Euskirchen than Duisburg. Time is an important factor in transporting LDHV goods. Figure 1 presents a summarized door-to-door time comparison between road and rail per route at $80 \%$ by rail. It shows that it would take around 2.2 times longer to transport $P \& G$ goods with the train (including pre- and endhaulage and using the standard loading and unloading methods, which require more time spent at each terminal). An important way of making better use of viable rail freight service is to apply cheaper and faster horizontal transhipment technique, for example, Innovatrain, which is discussed later.

\subsection{FloraHolland analysis}

The top down and bottom up analyses found that FloraHolland, one of the largest auction companies in the world, handled a total of 13,500 different types of floricultural products, including both cut flowers and plants, exported to 134 countries. Their customers (around 2,500) were exporters or wholesalers of horticultural products. FloraHolland's market share in Europe was c 60\%. In 2010, turnover was EUR 4.1 billion (EUR 4.2 billion in 2012). FloraHolland used transport services for a variety of horticultural products. Eight barriers were identified for transporting FloraHolland (and similar companies) products by rail:

1. The traditional expectation of customers in the horticultural industry was that the transport of perishable goods must be in road vehicles. This may be caused by, or be a cause of, barrier 2 .

2. The rail cargo industry's lack of understanding of the requirements of perishable goods. What are the preferences and characteristics and what choices must be made in the case of contingencies? The preferences of shippers of perishable goods were quite different from those of maritime cargo, or traditional rail cargo. To illustrate this: planners needed to be aware of the logistical characteristics of these products and to anticipate the events that could take place. This could differ from normal procedures, requiring better proactive communication and directly suitable solutions. Unlike traditionally rail transported goods, the customer held no safety stocks at destination, 
Table 1 P\&G Products' Operational costs on the selected network with less pre- and end-haulage

\begin{tabular}{|c|c|c|c|c|}
\hline Activity & Road $(100 \%)^{a}$ & Rail (60\%) & Rail (80\%) & Rail (87\%) \\
\hline Traction costs per year & - & $€ 2,500,000$ & $€ 2,500,000$ & $€ 2,500,000$ \\
\hline Wagon costs per year & - & $€ 140,160$ & $€ 175,200$ & $€ 198,560$ \\
\hline Handling costs per year & - & $€ 290,080$ & $€ 386,800$ & $€ 420,640$ \\
\hline Operational costs per year & $€ 3,601,834$ & $€ 2,930,240$ & $€ 3,062,000$ & $€ 3,119,200$ \\
\hline Operational costs per loading unit (average) & $€ 298.02$ & $€ 404.06$ & $€ 316.65$ & $€ 296.61$ \\
\hline Road transport costs for the remaining cargo by road & - & $€ 1,440,635$ & $€ 720,071$ & $€ 467,946$ \\
\hline Total operational costs per year & $€ 3,601,834$ & $€ 4,370,875$ & $€ 3,782,071$ & $€ 3,587,146$ \\
\hline
\end{tabular}

a Door-to-door road transport

requiring the total intermodal chain to act much more 'just in time', to higher service standards. This demands a change in thinking by the rail cargo industry.

3. Lack of business development effort by rail transport operators that focussed on maintaining existing services, to existing customers. There was little or no evidence of primary interest in new business.

4. Strong, proactive communication and innovative approaches are key to achieving a sustainable modal shift of perishable goods from road to rail. These were absent.

5. Rail operator service levels were generally the same for all types of cargoes; in reality, customers have a variety of differing needs, many of which were not being met.

6. Opening times at the destination terminals. Transport services were required over the weekend, to serve customers within 1 working day. Florists, wholesalers and retail companies required delivery on Monday morning, but this was prevented by Sunday closing at rail terminals. Cargoes arriving there on Sunday morning were parked for $20 \mathrm{~h}$.
7. The absence of a power and control system to supply and monitor refrigerated containers to carry temperature controlled goods on rail. Diesel powered alternatives failed when staff neglected to turn them back on after transport through tunnels, or between modes. This was inadequate and unacceptable for LDHV goods, specifically perishable and time critical goods like plants and flowers.

8. Waiting time during rail transport. There are valid reasons for stopping an international shuttle train, for example to change drivers. However, many stoppages could be avoided, principally those due to border crossing regulations, or time scheduling giving priority to passenger trains.

To overcome these barriers FloraHolland, and the association of horticulture exporters.

VGB, formed the "GreenRail" initiative, to facilitate modal shift for certain products to rail transportation, for customers in Italy, Hungary, Romania, Poland and Switzerland. GreenRail worked with the intermodal rail operator HUPAC for the execution of the rail transport, and with logistics management provider e-Logistics Control for operational management. The main objective

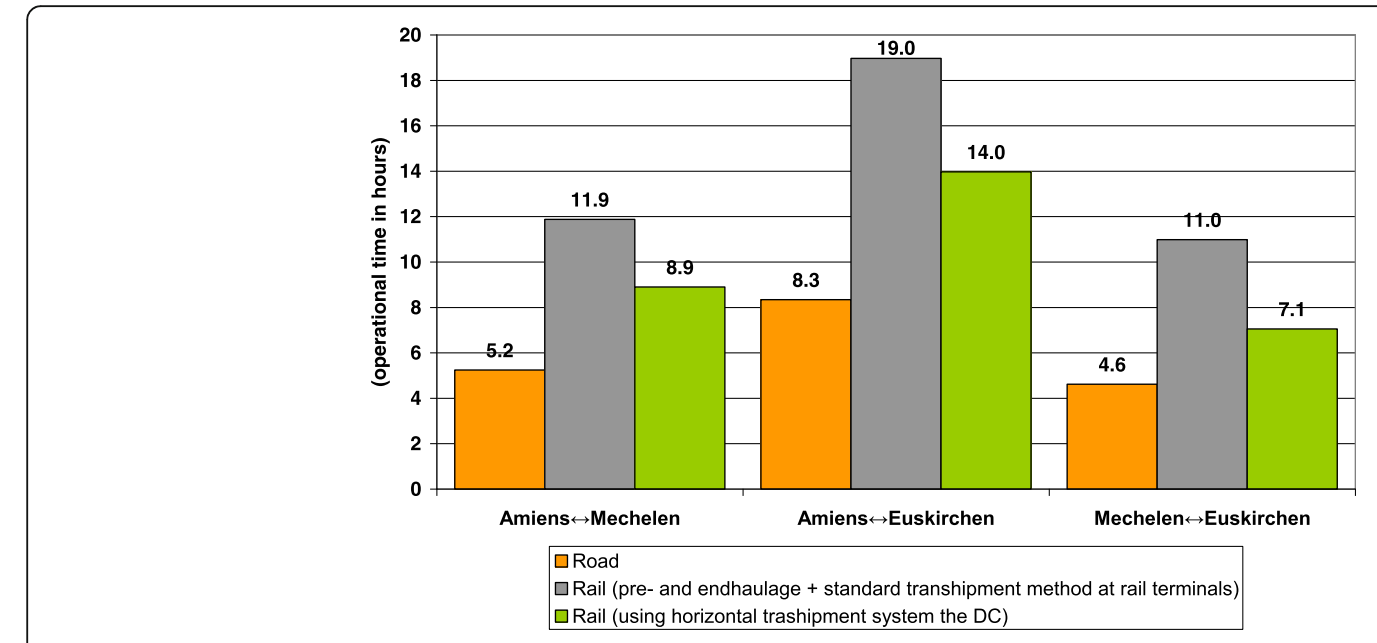

Fig. 1 P\&G door-to-door operational time per one-way trip, per modality and transhipment system 
of GreenRail was to develop an efficient, reliable and sustainable rail transport service for transporting ornamental plants, on several cross-border European corridors, and to demonstrate that logistics for time critical perishable products may be adequately served by rail.

FloraHolland acts as an innovative supply chain partner for the whole floricultural industry in the Netherlands. Within GreenRail they acted primarily as a supply chain facilitator, controlling the logistical information flow and developing innovative intermodal solutions. The challenge with GreenRail was to integrate the expertise of shippers, exporters, the traditional road sector, rail freight transport, and the world of logistics service providers, into a single solution. GreenRail bundled the know-how of exporters, transport and logistics service providers, and knowledge institutions into one concept, with FloraHolland the lynch pin between these cooperating players. The contracts were run by FloraHolland, acting as a kind of 5PL service provider (Fig. 2).

The entire transport and logistical operation consisted of three layers:

○ 3PL operations: truck transport and rail transport

- 4PL operations: chain coordination by e-Logistics Control

- 5PL operations: FloraHolland developed the chain and ran the contracts.

The 3PL operations were carried out by the rail operator HUPAC, ${ }^{8}$ which took care of the rail transport leg, set up the entire shuttle train business, and rented the traction service and wagons from railway undertaking DB Schenker Nederland. The pre- and post-road legs were served by 3PL service providers Van der Slot Transport ${ }^{9}$ and a number of transporters in Italy: GPA, VE Trasporti and Ewals. $^{10}$

The control of the supply chain and operational management was outsourced to e-logistics Control, ${ }^{11}$ a fourth party logistics service provider (4PL) owned by Ewals. Their main responsibilities were:

o selection of the international partners for distribution services in foreign countries;

o the execution of the transport services, 24/7; o 24/7 transport contingency solutions;

$\circ$ a feasible, developed intermodal chain;

$\circ$ the reliability of the intermodal chain;

o single point of contact for logistics parties and

horticultural customers;

o seeking backloads.

FloraHolland rented containers from leasing company Unit45 and arranged all contracts with HUPAC, the trucking companies in the Netherlands and Italy, and e-Logistics. In GreenRail, the intention was to make use of the proven and state-of-the-art technology and services, using existing equipment, transhipment hubs, terminals and services.

The GreenRail initiative ran from June 2009 to June 2010, transporting two or three containers of ornamental plants per week to Italy. Measured over a period of 1 year and a total of 90 shipments, $95 \%$ of containers arrived at destination on time, while the quality of the products was equal to road transport. The service is now commercially exploited by private logistics service providers and without the operational involvement of FloraHolland.

Table 2 presents the operational costs for road-only transport and for intermodal rail transport on the route Rotterdam, The Netherlands - Busto Arsizio, Italy. The cost calculation takes into account of comprehensive cost including transport costs, container rental costs, the diesel costs for controlling the temperature within the container, chain coordination costs. The calculation is made based on the following conditions:

- 75 roundtrips a year

- 80 containers in total.

- The distribution distance between the terminal Busto Arsizio to final premises of the customers is $50 \mathrm{~km}$.

As it can be seen from the Table 2, intermodal rail transport offers higher cost advantage as compared to road transport having two truck drivers, but it is more expensive compared to road transport with only one truck driver. A prompt overall transit time is very crucial factor in transporting flowers. Figure 3 presents a comparison of total transit time between road-only and intermodal

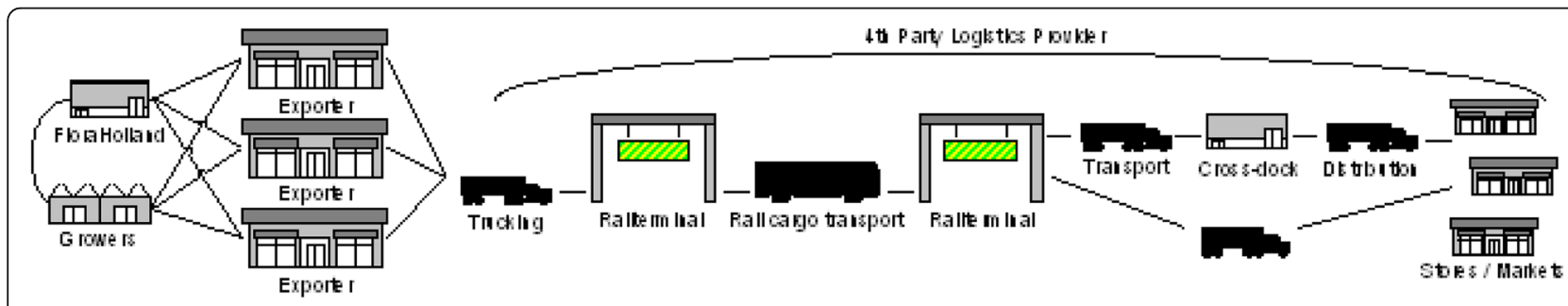

Fig. 2 Presentation of FloraHolland's door to door rail freight transport of horticultural products from Rotterdam (NL) to Busto Arsizio (IT) 
Table 2 Operational cost comparison between road-only transport and intermodal rail transport on route Rotterdam, The Netherlands - Busto Arsizio, Italy

\begin{tabular}{|c|c|c|c|}
\hline Items: & Road only (with one drivers) & Road only (with two drivers) & Intermodal rail \\
\hline Costs for pre- and post haulage per year & n.a. & n.a. & $€ 83800$ \\
\hline $\begin{array}{l}\text { Traction costs per year (Infrastructure, locomotive, } \\
\text { personnel, wagon costs) }\end{array}$ & n.a. & n.a. & $€ 88000$ \\
\hline Terminal handling costs per year & n.a. & n.a. & $€ 14400$ \\
\hline Container costs per year & n.a. & n.a. & $€ 12775$ \\
\hline Total operational costs per year & $€ 157500$ & $€ 195000$ & $€ 188075$ \\
\hline Operational costs per round trip & $€ 2100$ & $€ 2600$ & $€ 2450$ \\
\hline Operational costs per loading unit & n.a. & n.a. & $€ 2311$ \\
\hline $\begin{array}{l}\text { Operational costs per loading unit excluding pre- } \\
\text { and end haulage and handling costs }\end{array}$ & n.a. & n.a. & $€ 1301,87$ \\
\hline
\end{tabular}

rail transport on route Rotterdam - Busto Arsizio. It takes longer time for plants to be transported by intermodal rail than by road. Compared to a one truck driver scenario, it takes $60 \%$ more overall transit time by intermodal rail transport. Compared to the one-truck-driver scenario, it takes about twice the overall transit time to have the plants transported by rail. Ornamental plants, however, have a shelf-life of plants up to a few months and longer transit time form little problem for ornamental plants, as long as temperature can be controlled. Both products are high value products and therefore reliability in delivery and temperature are the most important factors that determine that the freshness and the commercial value of the products in the market.

\subsection{EURO CAREX analysis}

The Euro CAREX was a proposed European express rail freight service concept using the European high speed rail network and specially equipped TGV trains to transport goods traditionally delivered by air and express road freight modes. Individual CAREX sites were proposed at airports, including Paris CDG, Amsterdam Schiphol, Lyon, Cologne, and Liege airports, to link to the proposed
London CAREX site in East London to HS1 and the Channel Tunnel. Accuracy and promptness were seen as the key competitive factors of air freight carriers [30]. Freight forwarders had had a huge influence in the airfreight industry and remained a dominant force, accounting for more than $80 \%$ of the air cargo tonnage of the traditional airlines [31]. The express delivery industry had developed rapidly in recent years and attracted attention in many fields [32]. Within the Open Sky transport policy regime, air cargo markets had lowered unit cost, but resulted in a higher market concentration [33]. Keeping these aspects in mind, the bottom up analysis suggested that EURO CAREX was planning to offer three types of services with differentiated rates:

1) The "Express" service would be operated for reserved freight flows on the assigned train, with next-day delivery, guaranteed lead times, and flexible volume commitment. This new high-speed service, intended to capture modal shift from air freight, would set a higher price compared to other rail freight services, but charge around 10\% less than airfreight tariffs for express cargo.

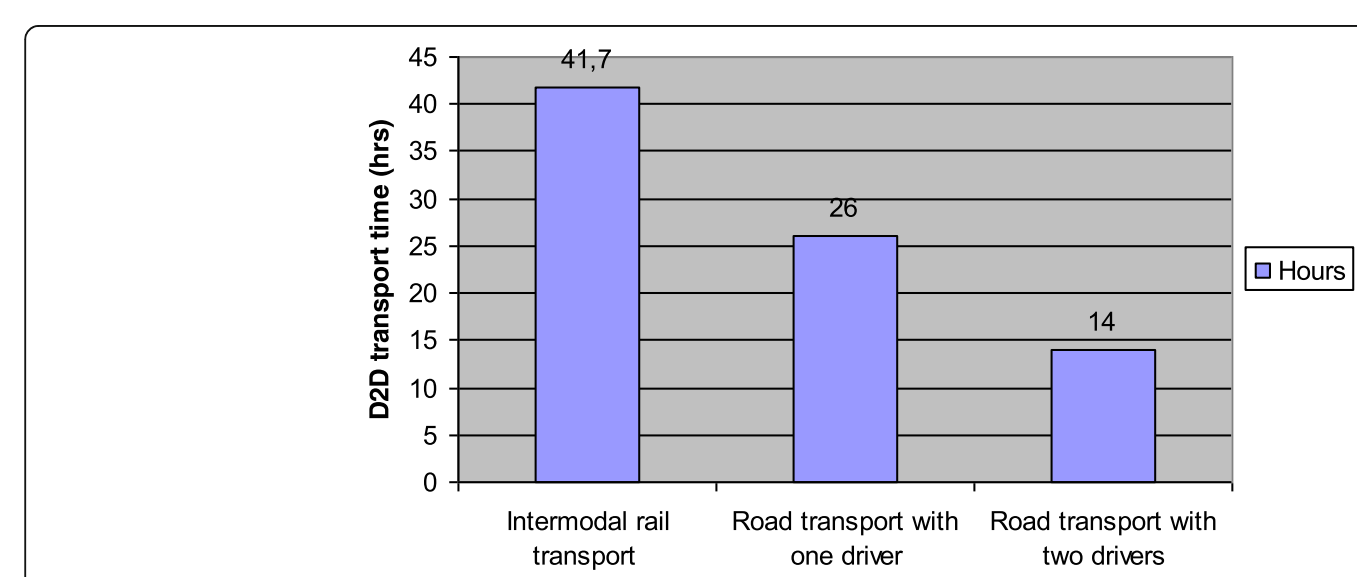

Fig. 3 Comparison of total transport time between road-only transport and intermodal rail transport on route Rotterdam - Busto Arsizio 
2) The "Rapid" service would be operated for reserved freight flows on the assigned train, with next-day delivery and guaranteed lead times, but with the possibility that flows may not travel on the assigned service, depending on train capacity. The price point of this type of service, designed primarily to capture trucked airfreight flows, would be lower than Express, but around 10\% above real airfreight trucking rates).

3) The "Deferred" service would be for freight flows travelling without reservation, offering delivery lead times of between one and 3 days, without guarantees; lead time and availability would be governed by train capacity (yield management). This service, to attract freight flows currently travelling by road heavy goods vehicle (HGV), would be set at a lower price point - just below the "Rapid" service).

EURO CAREX requested a study from the authors investigating the markets of the LDHV segment. Desktop research, of markets and transport statistics, was combined with interviews held with shippers, consignees and logistics service suppliers, and revealed a number of barriers to rail transport. For the airfreight market, the study detailed contrasting fortunes. The global airfreight market was buoyant; airfreight from/to the London area airports was consistently increasing and had reached an all-time high of $1.8 \mathrm{~m}$ tonnes transported, in 2010. However, airfreight volumes between the EU and London area airports were in decline. Freight and mail volumes between London area airports and specific individual CAREX destinations varied: Heathrow (via passenger aircraft) and Stansted (via cargo aircraft) demonstrated the largest volumes, with Heathrow to/from CAREX Frankfurt, and Stansted to/from Paris CDG, the most important routes.

Future demand was presented as two options: future demand up to 2025 based on GDP projections for the UK and CAREX site country, and future demand based on (declining) UK - EU airfreight trends. CAREX looked to position itself in a highly developed, mature and competitive market, made up of a mix of airfreight, airfreight by road, scheduled and spot road freight services (full and less than full loads), and the courier/white van sector. In order to prove successful over the longer term, there was a requirement for the EURO CAREX service to capture a share of the express road freight market.

The key issues to be addressed from this case were:

1. Perception: train operators were considered to be client unfriendly and non market orientated institutions;

2. EDI systems: train operators lagged behind third party logistics service suppliers, in terms of the availability, use and connectivity of integrated EDI-tracking, tracing and information systems;

3. Inevitable extra links in the chain of distribution: extra handling to get the goods on to the train, possibly increasing cost, time, and risk (of damage and theft);

4. Limitations: regarding the unusual size and nature of cargo, such as perishables, livestock and dangerous goods;

5. Lack of back up systems in case of calamity: rail operators' inability to organise alternative back up in the event of train system failure;

6. Flexibility: slot allocations forced a train to leave at its scheduled time, whereas a truck could wait for a solution to be found, in the event of short delays;

7. Costs: price was a main driver in possible mode switch: a switch to higher price/cost was unlikely;

8. Customs procedures: the concept should be able to handle bonded flows.

The expected time to be spent at the Amsterdam CAREX rail terminal, per logistics activity, is shown in Fig. 4. The total processing time at Amsterdam CAREX was expected to take no more than $2 \mathrm{~h} 30$, depending on the required consolidation process, the distance between the consolidation centre and the terminal, and the number of dolly trains used to transport the goods from the consolidation centre to the rail terminal.

The total processing time at London CAREX, with a consolidation centre located at the rail terminal, was expected to be lower than Amsterdam CAREX, where the consolidation centre would be around $1.6 \mathrm{~km}$ away, requiring dolly train(s) to drive back and forth to load and unload the goods. The expected loading/unloading time at London CAREX was $15 \mathrm{~min}$, compared to $30 \mathrm{~min}$ at Amsterdam CAREX. For this case study, the total processing time at London CAREX was assumed to be $2 \mathrm{~h} 15$.

The terminal layouts would be designed based on fast turnarounds: a train would spend a total of around $1 \mathrm{~h}$ at the terminal, during which time it would be loaded and unloaded.

\subsection{InnovaTrain analysis}

InnovaTrain AG, with the core business of delivering innovative solutions for rail freight over short and medium distances under economic viable condition, was founded in 2010 as a competence-centre for intermodal trains and transhipment concepts. Located in Bern $(\mathrm{CH})$ with a Head Office in Basel $(\mathrm{CH})$, the company's aim was to come up with innovative and economically feasible solutions for freight transport by rail within urban networks. The founding experts had formerly developed the "RailXpress Cargo-Shuttle", based on the passenger commutershuttle idea, which had been operating successfully since 


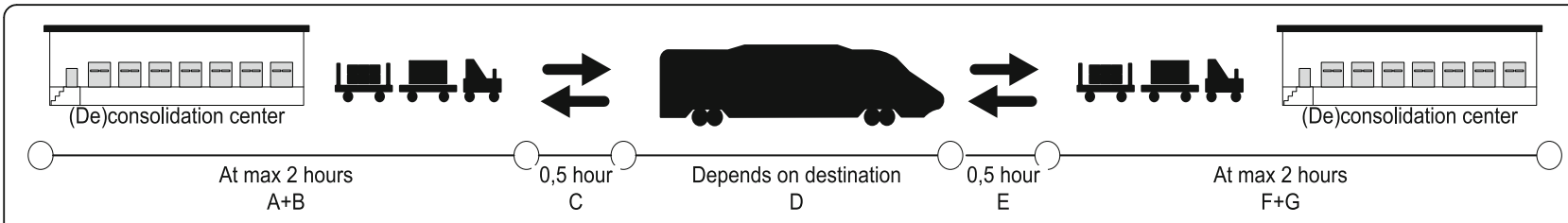

Fig. 4 Estimated time per logistics activity

its start in 2009. With the establishment of InnovaTrain, the experts aimed to spread their ideas across the whole of Europe.

The hybrid shuttle train deployed on the key route consisted of 5-10 permanently coupled container wagons, designed for standard intermodal transport units like swap bodies and ISO containers. With the help of hybrid power locomotives, the train could run on either the electrical main track, at speeds of up to $120 \mathrm{~km} / \mathrm{h}$, or drive into a private railway siding, or the a loading track of an intermodal terminal, using diesel power. Intermodal load transfer could be done using conventional vertical (lift on/lift-off) and/or horizontal transhipment technology; horizontal transhipment allowed load transfer to take place at any cargo station, or private railway siding, on an asphalted surface.

The InnovaTrain hybrid cargo-shuttle train system offered four major components:

- Hybrid power locomotive;

- Container wagon with detachable intermediate frame for horizontal transhipment;

- Transport unit (container/swap body);

- Horizontal load transfer technique.

The shuttle train observed in this case study was a push-pull train, capable of operating in either direction; to change direction, the driver simply walked to the other end of the train to take control from the other cab.

InnovaTrain behaved like a passenger train in terms of speed, acceleration, braking and momentum, allowing full scheduling on urban suburban and regional passenger train networks.

Interviewees reported an intensive co-operation and communication between the partners along the transport and logistics chain to be a key condition for the successful operation of an intermodal transport system. Considering the area, high frequency and short stops, the communication with partners had to be fast and highly reliable. Thus InnovaTrain also provided support for the implementation of IT systems, for operational management. The design of the logistical concept in the LDHV segment concerned not only the physical flow of the goods, but also the flow of information.

Intermodal load transfer was done using vertical (lift on/lift-off) and/or horizontal transhipment technology. Vertical transhipment implied the handling of the loading units by crane - as was the case in conventional intermodal rail-road terminals. For fast and flexible handling of the containers and swap bodies on rail sidings, the commutershuttle train relied on the "ContainerMover". This device, mounted on the truck, made possible an independent transhipment of standard $7.45 \mathrm{~m}$ swap-bodies, or $20^{\prime}$ containers, without need for dedicated infrastructure (e.g. transhipment terminal), as load transfer could take place at any cargo station, or private railway siding, on an asphalted surface only $4 \mathrm{~m}$ wide. This was considered an enabler for intermodal transport services.

The time spent at intermodal terminals in InnovaTrain was shorter than traditional rail operations. The next table underlines that the entire terminal process took little time - and even less human resource - ensured by using flexible direct transhipment between truck and railcar and shuttle trains that required no extensive shunting . Moreover, as the service studied was domestic, there were no customs operations or border crossing checks (Table 3).

The combination of ContainerMover and InnovaTrain operational innovation lowered transhipment costs from about 25 euro per movement to circa 13 euro. Transhipment costs, especially horizontal, have been repeatedly identified as a major barrier to intermodal freight traffic [10, 34].

InnovaTrain targeted RailCare, a Swiss cargo rail-road intermodal company, to adopt and offer this rail freight transport concept for the carriage of LDHV goods. Whilst the technology existed, some barriers were reported. These can be subdivided into logistical and regulatory (external) aspects, and rail technological and operational (internal) aspects. The external barriers were characterised as:

- Intense competition from the road transport sector, especially on price and transit time;

- Shippers felt more comfortable when ordering doorto-door road haulage, because it was convenient;

- A mental barrier, resulting in many shippers and freight forwarders neglecting the new opportunities to be gained from the use of alternative transport modes: they were resistant to changes in their logistical systems;

- The threat that the price offered by the InnovaTrain system could be abused by potential clients, in price negotiations with their sub-contractors (road carriers); 
Table 3 InnovaTrain Operations at Terminals

\begin{tabular}{ll}
\hline Indicators & Description of indicators \\
\hline $\begin{array}{l}\text { Intermodal service } \\
\text { Throughput time in origin terminal }\end{array}$ & $\begin{array}{l}\text { = closing time }- \text { availability time } \\
\text { = waiting time + time for inspection + shunting time + time } \\
\text { for loading/unloading + waiting time before departure }\end{array}$ \\
$\begin{array}{l}\text { Number of tracks in origin terminal (layout) } \\
\text { Throughput time in destination terminal on average }\end{array}$ & $\begin{array}{l}\text { = waiting time + time for inspection + shunting time + time } \\
\text { for loading/unloading on truck + waiting time for trucks to } \\
\text { pick up }\end{array}$ \\
$\begin{array}{l}\text { Number of tracks in destination terminal (layout) } \\
\text { Administrative/customs procedures at origin and destination } \\
\text { Inspection men }\end{array}$ & $\begin{array}{l}\text { Employees per shift } \\
\text { Shunting men }\end{array}$ \\
Staff executing loading and unloading & Employees per shift \\
\hline
\end{tabular}

- It still remains to be seen how the InnovaTrain concept works in a different environment (i.e. in a different country).

The internal barriers from the rail system itself provided some challenges for the InnovaTrain concept. For instance, capacity constraints in the rail network - especially the availability of daytime slots - should be mentioned. Although small in comparison to a dedicated terminal, sufficient availability of rail sidings for cargo handling purposes had to be provided by the railway infrastructure operating companies. Without these, the infrastructure investment - even if very limited in comparison to conventional intermodal terminals or single wagon loading installations - would still be substantial. It had to be guaranteed that trucks could carry out their handling on the paved surface alongside the rails. Finally, it may be the case that railway undertakings deliberately inhibited the development of the InnovaTrain system, for fear of loss of their rail freight business.

That said, the case study "InnovaTrain" showed that it is possible to carry LDHV goods by rail, in a cost-efficient manner. The case revealed that the transport service offered was able to compete with road transport, especially with regard to transport quality (transit time, reliability). This can be seen in the overview given in Table 4. The whole concept could be regarded as the blueprint for the development of an innovative rail freight services in the context of LDHV goods.

Table 4 Innovatrain comparison of costs with road transport

\begin{tabular}{llll}
\hline Criterion & InnovaTrain & $\begin{array}{l}\text { Road } \\
\text { transport }\end{array}$ & Remarks \\
\hline Transport costs & $€ 356.32$ & $€ 441.60$ & $\begin{array}{l}\text { Road: } 1.20 E U R / \mathrm{km}, 368 \mathrm{~km} \\
\text { total distance }\end{array}$ \\
Transit time & $8 \mathrm{~h} \mathrm{51}$ & $5 \mathrm{~h} \mathrm{25}$ & $\begin{array}{l}\text { Road: } 356 \mathrm{~km} \text { on motorways, } \\
12 \mathrm{~km} \text { other }\end{array}$ \\
\hline
\end{tabular}

Success factors were reported as: space accessibility and frequent availability of the service offering, high booking flexibility ( $1 \mathrm{~h}$ cut-off time), plus a centralised management and co-ordination of the transport service - either marketed to freight forwarding companies, or directly sold to shippers. A close co-ordination with shippers and logistics associations was also seen to be of importance. Finally, the success of this case was not based only upon a technical solution; rather, it was the result of a transport chain method: instead of focusing on purely carriage by rail, InnovaTrain created a door to door transport concept where rail provided the backbone over the longest possible stretch of the route.

\section{Recommendations for rail freight operations}

In this section we discuss the findings presented above focusing on rail operations, found to be a key source of barriers to, or enablers for, intermodal service for LDHV goods, both in the case studies and in the wider literature. It was identified in all cases that inefficient terminal operations often acted as a barrier to an efficient intermodal transport service along the selected routes, and ultimately to the modal shift from road to rail. The key barriers and relevant enablers for rail freight operations for LDHV goods are summarised in Table 5.

In the case of $P \& G$ it was identified that the volume of goods was insufficient for full trainloads. A less than full

Table 5 Barriers and Enabler to intermodal rail and LDHV goods

\begin{tabular}{lll}
\hline Barriers & Enablers & Additional enablers \\
\hline $\begin{array}{l}\text { Terminal to terminal } \\
\text { service }\end{array}$ & Door-to-door service & 3PL/Freight Forwarder \\
$\begin{array}{l}\text { Terminals as key } \\
\text { source of delay }\end{array}$ & $\begin{array}{l}\text { Improved and reliable } \\
\text { terminals }\end{array}$ & $\begin{array}{l}\text { Track side converted } \\
\text { into low cost terminal }\end{array}$ \\
$\begin{array}{lll}\text { Longer transit time } \\
\text { Introduce faster } \\
\text { service }\end{array}$ & More frequent service \\
$\begin{array}{ll}\text { Unreliable arrival } \\
\text { and departure }\end{array}$ & $\begin{array}{l}\text { Application of } \\
\text { integrated approach }\end{array}$ & $\begin{array}{l}\text { Supported by information } \\
\text { system }\end{array}$ \\
\hline
\end{tabular}


train fails to fully realise the economies of scale achievable through the use of rail freight, and the $P \& G$ case study identified that attention should be given to the bundling of goods. This refers to the aggregation of goods from a variety of shippers on the same rail freight vehicle, to ensure the train is fully loaded. Horizontal collaboration is viewed as a possible solution to the problem of bundling of goods. It aims to facilitate collaboration between shippers, by combining smaller shipments into a larger volume, more suitable for transportation by train. Bundling of goods can lead to economic, environmental and social benefits. Horizontal collaboration as described by Cruijssen et al. [35] requires that multiple independent shippers pro-actively work together in clusters or communities to "bundle" their overlapping freight flows. "Bundling" in this context means that the compatible freight flows of the shippers are consolidated in space, as well as synchronised in time. ${ }^{12}$

In light of this, increasing attention must be given to the process of facilitating collaboration. The interview with $P \& G$, for instance, specifically noted that they would look to collaborate/bundle goods with a "non-competing" partner. This sort of stipulation of course adds a degree of complexity to the process. In this sense the addition of a neutral 3rd party (logistics service provider or freight forwarder) is essential, especially when consolidating goods from a semi competing market. A freight forwarder (FF), not usually a carrier, but an intermediary between cargo interest and carrier, such as rail and road, has a major role - for example by arranging goods carriage between origin and destination. The FF may not conduct the carriage of goods but will accept the liability for the entire agreed carriage [36].

Of course, the environmental and other associated benefits of bundling of goods for intermodal service appealed to shippers (in particular of less-than truck load i.e. LTL cargo), but the service also had to make financial sense. For example, in a competitive market, a FF could offer reduced rates (cost) to shippers, compared to direct offer by the mail hauliers. The interview with $P \& G$ suggested that the cost for intermodal transport should be approximately $€ 1$ per $\mathrm{km}$ (per shipment) in order to compete with road transport. In this regard, it can be noted that, although the collection and delivery part (performed by road) of the intermodal service represented a smaller part of the total transport chain distance, it formed a significant proportion of the rate offered to shippers [37], accounting for up to $30 \%-40 \%$ of the total cost [10]. Furthermore, the trucking portion of a rail-truck intermodal service could cause serious problems in both productivity and service quality [37].

Taking into account the transhipment and third party costs, the rail freight operator would have to identify ways to reduce to cost. Also there were a number of operational requirements, such as a frequent service operated in conjunction with passenger timetables. Linking to the previous discussion, the bundling of goods could lead to increased volumes, facilitating a multi-stop service. The interview with $P \& G$ suggested that multi-stop train services were not feasible without fast and reliable transhipment, where a freight train stopped in a terminal for only short transit time - much like passenger train station stops. Such faster transhipment was unrealistic using traditional vertical transhipment techniques and equipment (forklift or gantry crane), leading us to recommend that a new transhipment technique would be required to reduce the building and operations cost of a rail terminal.

The FloraHolland case study presented a similar but also alternative set of issues and opportunities. Aside from any operational barriers that presented themselves, there was a clear lack of understanding in the rail sector about the transportation of refrigerated goods. All four case studies identified a demand for time sensitive/perishable goods to be transported by rail, but there were few initiatives or business development opportunities aiming to capture that demand. The requirement was not just the technical solution - a power and control system to adequately provide for the carrying of temperature controlled goods on rail - but also a change in thinking at strategic level within the railway industry, to engage with the market demand and operational requirements. To coin a phrase: 'no modal shift without mental shift'.

The FloraHolland case study also shared several similarities with the $P \& G$ case study in identifying terminal operations as a serious limitation of the rail network. In particular, long waiting times and limited opening hours did not suit the transport of FloraHolland's horticultural products. On top of this, a weekend service (i.e. 24/7 operation of terminals and transport services) was needed, to allow their customers to order goods on Friday and receive them in time for Monday trading.

FloraHolland expressed the requirement for a single point of contact, operated for example by a FF, for the entire intermodal transport chain. As in the P\&G case study, the single point of contact presents the opportunity to facilitate horizontal collaboration between semi-competing organisations to create full trainloads, multiple stopping points, and greater service frequency. FloraHolland also identified that the single point of contact should facilitate the integration between actors, and a tracking and tracing service for both cargo and cargo unit.

The FloraHolland case also identified a number of additional operational restraints, linked to excessive waiting times due to border crossings, driver changeover, and the prioritisation of passenger services.

The EURO CAREX study differed from the P\&G, FloraHolland and InnovaTrain case studies, in requiring large capital investment for specialist airfreight terminals 
at European hub airports, so that the main haul transport service between the hubs could be offered by rail, rather than air.

The InnovaTrain case presented a viable solution that had already been shown to work in practice and which contrasted starkly with the EURO CAREX vision, from a terminal perspective. The InnovaTrain solution proposed innovative, horizontal transhipment methods as a means of providing an austere terminal facility.

The InnovaTrain solution, in conjunction with intermodal operator Railcare, satisfied most of the requirements identified by $P \& G$ and FloraHolland. A shorter, faster and more flexible transhipment technique provided a higher frequency service, with short loading and unloading times, bringing goods closer to the end consumer and reducing the costly last-mile leg of the journey.

The InnovaTrain/ Railcare study proved that it is possible for rail to compete directly with road transport in terms of reliability, service quality and cost. The success factors for Innovatrain solution included:

- space accessibility and frequent availability of the service offering;

- a high flexibility concerning bookings (1 h cut-off time), plus a centralised management and co-ordination of the transport service, marketed either to freight forwarding companies or directly to shippers;

- close co-ordination with shippers, and between shippers and logistics associations;

- a transport chain method that went beyond the technical solution, instead of focusing on purely carriage by rail, providing a door to door service with rail forming the longest possible stretch of the route.

\section{Recommendations for practice and future service planning}

With the above findings, the research indicated that the InnovaTrain transhipment horizontal technique, in particular the aspect of rail-road intermodal terminal, was suitable for the transportation of LDHV, time sensitive goods by rail freight, in direct competition to road transport. From all four cases studies, it was clear that, without a freight integrator of some kind, rail operators were unlikely to succeed with purely technical solutions. Particular attention had to be given to the management and communication of information flow among the several actors or collaborating organisations [38], so the research recommended that the technical solution be complemented by a freight integrator who would provide the link between all main parties (rail and/or transport operators and shippers/consignees) and also aggregate cargo to realise full-load train service and eliminate empty running.

The EURO CAREX study was a large scale, capital intensive terminal solution, requiring high volume of traffic to amortise the highly automated systems. It was efficient at volume, but inflexible in terms of demand or market changes. On the other hand, the InnovaTrain transhipment technique presented some optimistic options for austere and yet flexible terminals. In addition to the benefits discussed in previous sections, it should be clear that this technique greatly reduced the need for terminal operational staff. The loading and unloading of containers/swap bodies, for example, could be conducted by the truck driver alone. The rail vehicle was stationary for only a short transit time - opined as a pre-requisite for using a rail-intermodal service - and the truck driver's one-to-one interaction with the cargo unit reduced the security threat to the cargo. The ability to effectively use any siding, or even the mainline, to create temporary 'terminals' meant that the solution added a flexibility to the rail freight sector that better suited modern logistics. However, for a rail freight service based on high volume, and therefore reducing marginal cost to very low levels, a fixed formation such as the EURO CAREX solution appeared more suitable.

Horticultural products, and other temperature controlled goods, required suitable containers and a terminal suited to both electrical power supplies to temperature controlled container and a power supply and control system to support the rail journey. These were not the only goods that required new thinking for modal shift to sustainable freight transport mode; fresh fish was once such further product type that emerged during the preliminary research, showing potentially large unexploited niches of the logistics market as available to pro-active entrepreneurs.

Proactive and adequate communication could enable the shipper of perishable goods to act in the event of a failure within the intermodal chain. In cooperation with its operational partners, FloraHolland and E-Logistics Control developed a complete contingency plan for the corridor Rotterdam - Italy. The needs of shippers and customers to track and trace LDHV goods along the supply chain, and not the locomotives or trains per se, meant that any new service offering should consider goods tracking, rather than vehicle tracking, integrated into a seamless information flow [39].

The InnovaTrain concept is very interesting due to fact that this is an example of intermodal rail service on shorter distances and for even smaller quantities which has not been managed in other countries. Here the key innovation is the horizontal container/ cargo unit mover system and the flexible train operation. For this, strong political commitment, as in Switzerland to give priority to rail freight compared to high truck fees and prohibition of truck transport in night time will be vital.

\section{Associated and ongoing research}

The work highlighted areas of technological, operations and business research that would yield both pragmatic 
commercial impact and valuable contribution to knowledge. Some were taken forward and acted upon [40], while some still await further attention. Technological research into developing commercially viable power and control systems for freight, in order to enable growth in temperature controlled goods, is a highly technological topic that has been brought to market by Faiveley Transport [28]. The development of seamless information flows between transport actors and modes advanced to the standardisation of the e-Freight (Common) Framework as ISO19845 [39, 41]. Tracking and tracing on railways advanced in multiple fashions, at the infrastructure level, the locomotive level and with examples of GPS devices on individual containers. Further work is needed to manage these approaches. Horizontal collaboration between non competing partners, and the role of freight integrators in that process, whilst advanced by the $P \& G$ case, would merit further research across all modes, and transfer into other problem fields of transport such as city logistics, where co-operation is often called for but rarely happens [42]. The technical solutions for these cases largely exist, and we suggest that concentrated cost-benefit analysis, combining traditional top down social analysis with bottom line entrepreneurial planning, is key [43]. The scheduling of faster freight trains on urban rail networks has been modelled in SIMUL8 and validated further [21].

\section{Summary and conclusions}

We have explained the context of the research: looking for experiences in the delivery of innovative rail freight services for low density high value (LDHV) goods, and engaging in methodologically pluralist case study research to identify barriers and opportunities in the single cases, triangulating those data to explore, describe and explain. We have reported recommendations for Rail Freight Operations and actions by case, and the analysis of barriers and opportunities this revealed, and made recommendations for those cases and also to the broader rail and logistics sector. We have also made recommendations for practice and future service planning for different cases. Associated and future research has been identified - and in some cases referenced - and we have summarised and concluded this research.

This case study research explored, described, and explained the barriers and obstacles, in two active and two planned LDHV rail services. It suggests that, to meet the potential demand of the market segment, technological, operational and business problems need to be solved, but it also suggests positive examples of how this might be achieved, to guide future managerial practice and service planning.

Reliability, price and time are the top requirements for LDHV goods. Particular attention is required in transporting time sensitive goods such as floricultural. The goods need to be delivered not too early since the flower shops are still closed; but also not too late since the shops are already opened. The just-in-time mentality needs to be carried by the stakeholders along the intermodal transport chain. Technology (e.g. horizontal transhipment or temperature control) plays a vital role in facilitating the use of rail services for time critical and temperature controlled products. Bundling of goods, through 3PL, is a necessity to realise low costs and commercially viable rail freight services.

\section{Endnotes}

${ }^{1}$ Speed of travel is the operational speed of the train in motion. Overall transit time is the time passed between commencement of the service and it's end, including all delays and stops in that service as well as time spent travelling.

${ }^{2}$ For more information on iTREN, see: http://www. tmleuven.be/project/itren2030/home.htm

${ }^{3}$ For more information on the estimated volumes for 2009, the chosen type of goods for the LDHV market and the assumption used for the forecasts, see http:// www.spectrumrail.info/

${ }^{4}$ GreenRail, an initiative of FloraHolland and VGB, organised rail transport of horticultural products via conventional rail links as a suitable and cheaper option for the long-distance transport of temperature controlled ornamental plant and flower products.

${ }^{5}$ Source: http://www.greenport.com

${ }^{6}$ Source: www.eia-ngo.com

${ }^{7}$ Source: http://www.greenport.com

${ }^{8}$ HUPAC website: http://www.hupac.com/

${ }^{9}$ Van der Slot transport website: http://www.vanderslot.nl

${ }^{10}$ Ewals website: http://www.ewals.com

${ }^{11}$ E-Logistics Control company website: http://www. e-lc.biz

${ }^{12}$ Source: http://www.co3-project.eu/

Authors' contributions

Both authors conducted the research within an EU project team of which THZ was the Principal Investigator and Co-ordinator. DMZI took the lead for this journal paper with THZ editing and finalising the text. Both authors read and approved the final manuscript.

Competing interests

The authors declare that they have no competing interests.

\section{Publisher's Note}

Springer Nature remains neutral with regard to jurisdictional claims in published maps and institutional affiliations.

Received: 8 July 2016 Accepted: 19 April 2018

Published online: 11 June 2018

\section{References}

1. Department for Transport, 2011. Realising the potential of GB rail final Indepdent report of the rail value for money study,

2. Drew, J., 2010. Rail FREIGHT : the benefits and costs of vertical separation and open access, 
3. den Boer $\mathrm{E}$ et al (2011) Potential of modal shift to rail transport study on the projected effects on GHG emissions and transport. Community of European Railway and Infrastructure Companies (CER), Delft

4. Grant D, Rautrims A, Wong C (2013) Sustainable logistics and supply chain management: principles and practices for sustainable operations and management. KoganPage, London

5. McKinnon, A., 2007. CO2 emissions from freight transport in the UK, report prepared for the climate change working Group of the Commission for integrated transport,

6. European Commission (2011). WHITE PAPER roadmap to a single European transport area - towards a competitive and resource efficient transport system, Brussels. Available at: http://eur-lex.europa.eu/legal-content/EN/ALL/ ?uri=CELEX:52011DC0144. Accessed 10 Feb 2018.

7. Psaraftis, H.N. 2015. Transportation logistics associate series editor

8. Psaraftis HN, Panagakos G (2012) Green corridors in European surface freight logistics and the SuperGreen project. In: 4th conference transport research arena. Elsevier Procedia - Social and Behavioural Sciences, Athens, pp 1723-1732

9. Meinert $\mathrm{M}$ et al (2015) Benefits of hybridisation of diesel driven rail vehicles: energy management strategies and life-cycle costs appraisal. Appl Energy 157:897-904 Available at: http://linkinghub.elsevier.com/retrieve/pii/ S0306261915006686 [Accessed 4 Mar 2017]

10. Janic M (2008) An assessment of the performance of the European long intermodal freight trains (LIFTS). Transp Res A Policy Pract 42(10):1326-1339 Available at: http://linkinghub.elsevier.com/retrieve/pii/S0965856408001213 [Accessed 24 Jan 2011]

11. Zunder TH et al (2013) How far has open access enabled the growth of cross border pan European rail freight? A case study. Research in Transportation Business \& Management 6:71-80 Available at: http://linkinghub.elsevier.com/ retrieve/pii/S2210539512000983 [Accessed March 25 2013]

12. Islam DMZ, Ricci S, Nelldal B (2016) How to make modal shift from road to rail possible in the European transport market, as aspired to in the EU transport white paper 2011. Eur Transp Res Rev. Available at: https://ink springer.com/article/10.1007/s12544-016-0204-x. Accessed 10 Feb 2018.

13. European Commission, 2014. EU transport in figures - statistical pocketbook 2014,

14. European Commission, 2016. Transport in figures statistical pocketbook 2016,

15. Islam DMZ, et al (2015) Assessing the impact of the $2011 \mathrm{EU}$ transport white paper-a rail freight demand forecast up to 2050 for the EU27. Eur Transp Res Rev 7(3):22 Available at: http://link.springer.com/10.1007/s12544015-0171-7. Accessed 24 June 2015.

16. Department for Transport (DfT), 2016. Future potential for modal shift in the UK rail freight market

17. Department for Transportation (DfT), 2016. Rail freight strategy,

18. Jackson R, Islam DMZ, et al (2013b) The potential of low density high value rail freight market in Europe, 13th world conference on transport research, pp 1-23. WCTRS 2013, Rio de Janeiro

19. Jackson R et al (2014) A market analysis of the low density high value goods flows in Europe. In: Selected proceedings: 13th world conference on transport research (WCTR). 2014, Rio de Janeiro: COPPE - Federal University of Rio de Janeiro, Brazil In: Select, pp.1-12

20. Bärthel F, Woxenius J (2004) Developing intermodal transport for small flows over short distances. Transp Plan Technol 27(5):403-424

21. Singhania $V$, Marinov M (2017) An event-based simulation model for Analysing the utilization levels of a railway line in urban area. PROMET - Traffic\&Transportation 29(5):521 Available at: http://www.fpz.unizg.hr/ traffic/index.php/PROMTT/article/view/2306 [Accessed 8 Feb 2018]

22. Woroniuk, C. et al., 2013. Time series analysis of rail freight services by the private sector in Europe. Transp Policy, 25(null), 81-93. Available at: https://doi.org/10.1016/j.tranpol.2012.09.004 [Accessed 25 Mar 2013]

23. Jackson R, Matsika E et al (2013a) Conceptualisation of an innovative rail freight vehicle for transporting LDHV cargo in an EU context. In: World congress on railway research (WCRR). WCRR, Sydney

24. George A, Bennett A (2005) Case studies and theory development in the social sciences, MIT Press, Cambridge

25. Eckstein H (1975) Case study and theory in political science. In: Greenstein Fl, Polsby NW (eds) Handbook of political science. Addison-Wesley, Reading, pp 79-137

26. Gerring J (2007) Case study research principles and practice. Cambridge University Press, Cambridge
27. Yin RK (2014) Case study research: design and methods fifth edit. SAGE Publications, Los Angeles

28. Jackson R et al (2015) SPECTRUM final Report_D4.5_Final, Newcastle upon Tyne Available at: https://www.scribd.com/document/341163228/ SPECTRUM-Final-Report-28082015-Ver-1-2

29. Cruijssen FCAM (2006) Horizontal cooperation in transport and logistics. Tilburg University, CentER

30. Park Y, Choi JK, Zhang A (2009) Evaluating competitiveness of air cargo express services. Transportation Research Part E: Logistics and Transportation Review 45(2):321-334

31. Zhang A et al (2007) Intermodal alliance and rivalry of transport chains: the air cargo market. Transportation Research Part E: Logistics and Transportation Review 43(3):234-246

32. Yang $\mathrm{H}$ et al (2009) Insight to the express transport network. Comput Phys Commun 180(9):1511-1515

33. Yamaguchi K (2008) International trade and air cargo: analysis of US export and air transport policy. Transportation Research Part E: Logistics and Transportation Review 44(4):653-663

34. Bontekoning Y, Priemus H (2004) Breakthrough innovations in intermodal freight transport. Transp Plan Technol 27(5):335-345. https://doi.org/10. 1080/0308106042000273031

35. Cruijssen F, Cools M, Dullaert W (2007) Horizontal cooperation in logistics: opportunities and impediments. Transportation Research Part E: Logistics and Transportation Review 43(2):129-142 Available at: http://linkinghub. elsevier.com/retrieve/pii/S1366554505000943 [Accessed 19 Feb 2017]

36. Islam DMZ, Dinwoodie J, Roe M (2006) Promoting development through multimodal freight transport in Bangladesh. Transp Rev 26(5):571-591 Available at: http://www.informaworld.com/openurl?genre=article\&doi=10. 1080/01441640600576902\&magic $=$ crossref\%7C\%7CD404A21C5BB053405B1 A640AFFD44AE3 [Accessed 2 Feb 2011]

37. Morlok, E.K. \& Spasovic, L.N., 1994. APPROACHES FOR IMPROVING DRAYAGE IN RAIL-T ... Page 1 of 35 APPROACHES FOR IMPROVING DRAYAGE IN RAIL-T ... Page 2 of 35 ,

38. Islam DMZ, Blinge M (2017) The future of European rail freight transport and logistics, pp 10-11

39. Zunder T et al (2012) Is it possible to manage and plan co-modal freight transport without a centralised system? International Journal of Applied Logistics 3(2):25-39 Available at: http://services.igi-global.com/resolvedoi/ resolve.aspx?doi=10.4018/jal.2012040103 [Accessed 22 Oct 2012]

40. Capacity4Rail Project, 2014. Requirements toward the freight system of 2030/2050 - intermediate report, deliverable 21.1,

41. ISO/IEC_JTC_1, 2015. ISO/IEC 19845:2015 information technology - universal business language version 2.1 (UBL v2.1)

42. Dablanc L (2007) Goods transport in large European cities: difficult to organize, difficult to modernize. Transp Res A Policy Pract 41(3):280-285. Available at: http://linkinghub.elsevier.com/retrieve/pii/S0965856406000590. Accessed 14 Oct 2015

43. Siciliano $\mathrm{G}$ et al (2016) Adapted cost-benefit analysis methodology for innovative railway services. Eur Transp Res Rev 8(4):23 Available at: https://doi.org/10.1007/s12544-016-0209-5

\section{Submit your manuscript to a SpringerOpen ${ }^{\circ}$ journal and benefit from:}

- Convenient online submission

- Rigorous peer review

- Open access: articles freely available online

- High visibility within the field

Retaining the copyright to your article

Submit your next manuscript at $>$ springeropen.com 